\title{
Digital Conversations on the Blogosphere
}

Adeola Abdulateef Elega, Eastern Mediterranean University, North Cyprus

\begin{abstract}
Blogs or weblogs are shared online journals that allow individuals or groups to share entries about their experiences, ideas and opinions. One of its common feature; the comment section, is the major facilitator of digital conversations on the blogosphere and it has earned little scholarly effort unlike news entries. Through a qualitative research technique of in-depth interview among fifteen active blog visitors of Linda Ikeji, a Nigerian A-list blog, this study sought to understand why blog readers involve or engage themselves in digital conversations on blogs. Findings show that that blog visitors seem to be primarily motivated to involve themselves in digital conversation for three main reasons; opinion sharing (Checking other commenters/ blogger and, alternating the dominant flow of conversation) digital conversational perks and interest.
\end{abstract}

Keywords: blogs, blog users, comment section, digital conversations, Linda Ikeji blog 


\section{Introduction}

A blog is a website with news entries, presented in reverse chronological order. It is typically text-based but it also allows other multimedia files such as videos, images and audio (Nardi, Schiano, \& Gumbrecht, 2004; Elega \& Özad, 2017). Whilst it is difficult to mark the beginning of weblogs, many believe that blog author, Jorn Berger coined the term 'weblog' in 1997 (Turnbull, 2002) and, it was re-coined to 'blog' from 'wee-blog' by web developer Peter Merholz in 1999 (Siles, 2012).

Over the years, blogs have evolved and majority of the newer blogs create new content rather than take from other internet sources. Majority of the newer blog authors are committed to sharing their personal ideas, thoughts, experiences and worldview. Many of these weblogs focuses on a variety of topics and they are built on author's personality, intrinsic and extrinsic motivation. News entries are determined based on blog authors' day to day live and what he decides to put up on the webpage (Rodi, 2002). Some blog authors also write about the world, notable people, other weblogs or websites and this helps them to ascertain their relationship with the world outside of the one they exist (Ewins, 2005).

Blogs have been particularly popular and influential. Considering the millions of blog authors and readers, the net is significantly changing because instead of just being passive consumers, internet users are constantly creating content and becoming active users of the platform (Stern, 2008). The weblog allows for digital conversations; linking and commentary are two of the most important facilitators of digital conversations, relationship development and community building on the blogosphere but for the purpose of this study, we focus on commentary.

Considering that "The role of this ever increasing population of blog readers presents a promising and important, yet little-explored, area of research" (Baumer, Sueyoshi, \& Tomlinson, 2008 p. 1111). Hence, this study asks, why do blog readers involve themselves in digital conversations. 


\section{Literature Review}

\section{The 'Art' of Conversation on Weblogs}

Weblogs provide content and also facilitate interpersonal relations (Kaye \& Johnson, 2011) because most weblogs allow blog readers to comment on news entries. This also generates easy familiarity and sociability among blog readers and even blog author on the blogosphere (Bukvova, Kalb, \& Schoop, 2010). Conversations on weblogs can be easily likened to a phone call or face-to-face discussion or even an articulated conversation drawn from the response to a missive. As humans, we harbour ideas for a while that it quickly stays uppermost in our minds and we still don't feel compelled to reply as soon as the other party speaks. Conversations on blogs can stop and start, with periods of intense discussion broken up by long gaps, while still maintaining the thread of an ongoing discussion about a particular subject by linking back to archives of past comments (Ewins, 2005).

Weblog conversations are integral parts of blogs. They define what makes a blog interactive and to a great extent, they also determine what makes a blog A-list or popular because the back and forth of conversations of weblogs, keep blog commenters engaged with the activity, keeps blog readers in tune with updates and keep lurkers around more than non-interactive blogs. Just like in traditional media such as radio, television, newspaper and, magazines, weblog conversations significantly drive the advertising part of blogging. Majority of the companies or advertisers, are concerned about how engaged their target audience are with the blog so this is to say as Nardi et al (2004) put it "blogs create the audience, but the audience also creates the blog" (p. 224).

As humans, we want to belong or be known to a community or keep company with or hang out with people of like minds or sometimes opposing minds. Interactive blogs facilitate networking and also give users an online community where they can create and maintain relationships. According to one of the respondents in Elega and Özad's (2018) study. He said;

I had issues in my relationship then if I could recall. I was so down and depressed so I sort for some closure to feel good. So, while going through my Facebook timeline. I saw a post by a friend and when I clicked the post, the post directed me to where my friend lifted the story from and it was from a blog, Linda Ikeji. That was around 2010. So when I got on the blog, I read the story. If I could remember it was about a woman complaining about her husband cheating on her, so after commenting, the 
readers there loved my comment, some were even asking me if they could copy my comment and make reference to it. I was happy, I found a place that could distract me from my depression and make me feel good again. I found a sort of a new family (p. 6).

Unlike everyday conversations, discussions on weblogs occur in a structured format. Some known members moderate the blogging discussion by commencing conversations while other members contribute and participate in the conversations (McGlohon, Leskovec, Faloutsos, Hurst, \& Glance, 2007). The emergence of digital conversation on weblogs is highly determined by the post entries. Considering that every blog has its own audience and target audience, overtime new readers are exposed to conversations on weblogs. Sometimes they are not aware of where the conversation started from and they may not have the ability to trace it (Efimova \& De Moor, 2005).

According to Reid (2011), “...comments also have their drawbacks. The most obvious of these is comment spam. Much like email spam, comment spam are random comments on your posts that include links to (often questionable) websites" (p.318).

\section{Related Studies}

Herring, et al., (2005) explores the degree and pattern to which A-list and non A-list weblogs are connected by asking two major research questions; to what extent are regular or non Alist blogs interlinked and, do various forms of conversations occur between related blogs, and to what degree? This study follows a quantitative social network investigation. Results show that A-list blogs are represented in a disproportionately large number while other non A-list blogs were more densely interrelated. The study also found that the way most of the weblogs in the sample linked, the blogosphere is periodically conversational and interconnected to some degree interconnected.

Lehti (2013) investigates conversations between poilticians' blog in France. In the paper, Lehti claims that despite the interconnectedness ongoing in public discourses, it isn't the case with French politicians' blogs. The study's research material includes 874 news entries published in 80 French politicians' blogs. All blogs are managed by politicians themselves; 79 politicians managed each and one politician managed two weblogs. Analysis focused on 
the month of September 2007. The study focuses on this specific tool of computer mediated communication (CMC) because in 2007, the weblog was the most significant form of networking site used by politicians. All blogs were analysed from a persuasive perspective as an instrument used to create a factual image of a blogger. Findings show that while a handful of the conversationalised weblogs make the blogger look like a regular person who has the public at heart, majority of the blogs construct an image of authoritative image for the blog authors.

Vuorinen (2017) explores the prospects, advantages and limitations of using weblogs for discussion. Blog corpus was obtained from the blogs that partook in Blogtalk conference in 2003. For the qualitive evaluation of the study, blog posts that focused on the conference were evaluated. To present a comprehensive comparism of forums, The CHIplace discussion forum was selected to equate Blogtalk. Results show that blogs are important for discussion. It was found that blogs had some unique features that make it look different from a discussion forum; digital conversations run through various posts on the weblogs. To manage discussions among blog authors, hyperlinks are highly instrumental. Trackback and comments help facilitate and manage conversations on the blogosphere. The dispersed model of blogging makes it difficult for blog readers who are not blog authors themselves. Result also shows that blogging makes it possible for blog authors to blog live from an occasion or happening.

Walker (2006) explores commenting on political blogs. The study starts by asking what impact does political blogs have on the everyday peoples' information reality. A pilot study was conducted to understand political blogs as a platform that supplies information to the populace. While the study evaluates that, it also explores the commentary posted on the new entries of political weblogs. Research materials include two mainstream media with nearly the same characteristics of blog columns and four A-list political weblogs. To have varied ideological standpoints; two conservative weblogs (Captain's Quarters and PoliPundit) and two liberal blogs (Washington Monthly and DailyKos) were chosen. Considering the number of weblogs available, the study focused on A-list blogs. Results show that comments aligned with the various ideological spectrum. At points where opinions differed, comments came from blog readers with highly intensified views. Blog readers with neutral viewpoint weren't found and comments from the minority group were regarded mostly as people who comment 
just to annoy other blog readers. Result also shows that blog commenters often identify each other through feedback, user name, citation from new entries, or questions. The study concludes that the findings reveal that communities are growing on weblogs.

Sankaram and Schober (2015) studied commenting, posting and lurking on the blogosphere. The study evaluates the blog readers on interactive and non-interactive blog. For the purpose of the study, a website was created (www.thepublicsphereblog.com). News entries on the blog were primarily content about 2012 U.S. presidential election. Respondents were enrolled through email, Facebook and news entries on Craig's List (Los Angeles, Detroit, Dallas, Denver, New Orleans, New York, Chicago, Minneapolis, Albany, Boston, Philadelphia, Atlanta and San Francisco). Adverts revealed an incentive for respondent's and Seventy-six people enrolled from the website. Six respondents visited the website just one time and for that reason, they weren't drafted for the final sampling. 70 respondents (37 men and 33 women) were included. Results reveal that blog readers of interactive blogs participate more in information processing on the weblogs differently from weblogs that allow no comment.

\section{Methods}

Studies on blogs are myriad and most of them have used quantitative methods to analyse blogs. In this study, the researcher decided to use a qualitative research method of in-depth interview because according to Hookway (2008) "One area that has yet to be developed by social scientists as a rich source of qualitative data is the weblog" (p. 92). Blog readers of Linda Ikeji blog; a Nigerian A-list blog that has been credited with a high and rich history of audience engagement was focused on to collect data for this study. The entry used as the population was entitled "and it's the first lib giveaway of 2016". As of July $28^{\text {th }} 2016$ when the mail addresses were obtained, the original post had 11,159 comments.

To get a sizeable sample of blog users for this study, 200 respondents who put their mail information on a blog entry was contacted. Two blog users who added their telephone numbers within our sample frame were also contacted via Telbo VoIP call. Many blog users posted their addresses multiple times but researcher checked and sorted them carefully to ascertain that only one address was picked for a single commenter. The email addresses of four out of the 11 blog users whom the blog author identified as the most consistent readers of her blog in 2015 were also added, making the total number of blog readers contacted, 204. 
On December $5^{\text {th }} 2016$, an email containing the invitation missive was sent to 204 potential interviewees and only one respondent reacted, then, researcher had to provide incentive to potential respondents. On December $26^{\text {th }}, 2016$, the researcher sent the second email containing research invitation letter and promised to provide 300 Naira airtime top-up for any respondent who acquiesced to participate in the study. Seven respondents reacted and through snowballing sampling, the researcher reached eight other interviewees within the sample frame making the total of blog readers 15. This total number was proved to be justifiable according to Bauer and Gaskell's (2000). They said, for any interview-based study by one researcher to be valued, the total number of interviewees should be between 15 and 25 interviews.

All consultations were done using WhatsApp Calling and Telbo MobileVOIP caller between January 3rd and March 6th 2017. Consultations were mostly conversational. Most interrogations centred on blog readers' involvement in digital conservations and blog reading practices. All interviews were conducted in English language. Interviews lasted between 25 to 35 minutes and all patterns identified, thematically analysed (Braun and Clarke, 2006).

Table 1: Profile of participants

\begin{tabular}{|c|c|c|c|c|c|c|}
\hline Name & Age & Gender & $\begin{array}{l}\text { Marital } \\
\text { Status }\end{array}$ & $\begin{array}{l}\text { Current } \\
\text { Educational } \\
\text { Level }\end{array}$ & Occupation & $\begin{array}{l}\text { Years of } \\
\text { Visiting }\end{array}$ \\
\hline Azuibike & 32 & $\mathrm{~F}$ & M & College graduate & Entrepreneur & 4 \\
\hline Godwin & 21 & M & S & College graduate & Freelance writer & 6 \\
\hline Olarenwaju & 28 & $\mathrm{~F}$ & $S$ & $\begin{array}{l}\text { Higher National } \\
\text { Diploma (HND) } \\
\text { graduate }\end{array}$ & Banker & 5 \\
\hline Madu & 33 & $\mathrm{~F}$ & M & College graduate & $\begin{array}{l}\text { Job hunting } \\
\text { (former banker) }\end{array}$ & $\begin{array}{l}\text { More than } \\
5\end{array}$ \\
\hline Obia & 35 & $\mathrm{~F}$ & $S$ & $\begin{array}{l}\text { College of } \\
\text { Education }(\mathrm{COE}) \\
\text { graduate }\end{array}$ & Job hunting & 4 \\
\hline Lambert & 37 & $\mathrm{~F}$ & M & HND Graduate & Secretary & $6-7$ \\
\hline
\end{tabular}




\begin{tabular}{|c|c|c|c|c|c|c|}
\hline Mthithi & 22 & M & $S$ & Undergraduate & Student & 6 \\
\hline Sarunmi & 21 & M & $\mathrm{S}$ & Undergraduate & Student/ & 6 \\
\hline & & & & & \multicolumn{2}{|l|}{ Entrepreneur } \\
\hline Benedict & 20 & M & $\mathrm{S}$ & Undergraduate & Student & $5-6$ \\
\hline Aremu & 48 & M & $\mathrm{M}$ & College graduate & Industrial chemist & 7 \\
\hline Daramola & 30 & M & M & $\begin{array}{l}\text { Post Graduate } \\
\text { degree }\end{array}$ & Civil servant & $5-6$ \\
\hline Nnags & 27 & M & $\mathrm{S}$ & College graduate & Firm secretary & 7 \\
\hline Bislam & 28 & $\mathrm{~F}$ & $\mathrm{~S}$ & College graduate & Civil servant & 6 \\
\hline Priesthood & 35 & M & M & College graduate & \multicolumn{2}{|c|}{$\begin{array}{l}\text { Human resource } 9-10 \\
\text { practitioner }\end{array}$} \\
\hline Aliyu & 22 & $\mathrm{~F}$ & $\mathrm{~S}$ & College graduate & $\begin{array}{ll}\text { National } & \text { Youth } \\
\text { Service } & \text { Corps } \\
\text { (NYSC) } & \end{array}$ & 5 \\
\hline
\end{tabular}

Overall, researcher questioned fifteen participants and demographically, male and female respondents were almost equally distributed. Female participants were seven and male were eight. Interviewees ranged between 20 to 48 years old; for the age set; 20, 21, 21, 22, 22, 27, $28,28,30,32,33,35,35,37$ and 48, participants median is 28 years old. All but six interviewees are single. Most of the participants have college degrees (B.sc, B. Tech, B.A) and their occupation range from HR practitioner, freelance writer, NYSC member, entrepreneur, banker and civil servant. Majority of the interviewees have been visiting the Linda Ikeji blog for at least four years.

\section{Results}

This study explores why blog readers involve themselves in digital conversations on the weblogs and found myriad factors why they do. Among the many, three themes were identified and isolated; opinion (Alternating the dominant flow of conversation and checking the other commenters/ blogger), digital conversational perks and interest.

\section{Opinion Sharing}

Since time immemorial, it has been documented that people engage in conversations to share their personal beliefs or judgments on certain issues. For weblog users, it isn't exactly 
different. Eight of the blog users interviewed accede that airing their sentiment or changing the narrative or checking the blogger or other blog commenters is why they involve themselves in the conversational activity of blogging. When asked why interviewees involve in digital conversations on the blogs. 32 years old entrepreneur, Azuibike states that "For me to comment, she's airing my opinion or to agree or disagree on something. I always want my opinion known on a particular story or event, then I'll definitely comment on it. I always comment and don't just pass because I want my observation to be known or read". While many interviewees mirrored this finding; some others assert that they like to hear about the opinions of other users. So they write to support it or alternate the dominant discourse.

\section{Checking Other Commenters/ Blogger}

Blog users examine the comments of other blog users in the comment section so as to determine accuracy, morality, among other things. 21 years-old freelance writer, Godwin accedes that he likes airing his opinion on certain issues, sometimes unpopular and sometimes highly controversial. He further said when asked how he handles backlash for some of his comments that; “Generally, I don't think the way most Nigerians think, I am very liberal on so many situations. So if they see my comments as immoral or ungodly, I just ignore but sometimes, I do put them in their place'. Researcher asked for an example and he said,

Mostly on LGBT topics. They tend to be very insulting when it comes to those set of people but I am very defensive of those set of people. They are always insulting me that I will go to hell fire and I reply most times that I don't believe in religion, I don't believe in hell fire, I don't believe in your God or your bible. So how would something I don't believe in punish me. So situations like that mostly.

Nigeria been a highly conservative, religious and a society with a law that criminates samesex relations, Godwin's discourse will most likely come with a lot of backlash and criticism. Despite the fact that blogs, Facebook and other computer mediated communication tools has become a safe place for Nigerian gay men and women to engage, communicate, connect, and share thoughts, ideas, opinions in public (Ifekandu, 2017). Clarifications on the kind of internet platform that promotes discourses on such topics matter. Considering that Linda Ikeji blog is still like the traditional public sphere owing to the fact that it is a general information with different types of people, comments promoting LGBTQ will be scrutinized. For special 
interest gay groups such as BLK, Gayromeo, Gaydar, and Manjam platforms, it is clear that might be no 'checking' per se. Ifekandu's (2017) adds that “. Chat rooms and group pages have also been created by some of the gay key opinion leaders in Abuja, Lagos, Enugu, Calabar and Port Harcourt" (p.850).

Examining the blogger has been a major discourse in blogging communities and forums given the fact that a handful of blog readers are 'information junkies', sometimes, they get to the story before the blogger or even better, sometimes they have a more complete and indepth story than the blogger. Blog author of Drudge report, Matt Drudge, accede that one would be surprised what the common man knows (as cited Wheeler, 2008). When asked why she involves herself in digital conversations on the weblog, 28 years old banker, Olarenwaju said;

Maybe Linda carried a wrong news and I had read it, maybe I stumbled on it on the TV before. ...Maybe it happened two years ago and she is still saying, I would be like that's stale, this happened two years ago.

This is in line with Baumer, Sueyoshi, and Tomlinson's (2008) study. They said that four interviewees state that they comment to spite the blogger or digitally invade her personal space. 33 years old Graduate student, Lillian who visits the following blogs; blogspot.com, indigirl.com/blog, carrieoke.net, doggedknits.com states that there is no point posting negative comments on blog entries. She adds that she makes sure that whatever she shares has to be positive. Unlike, Lilian, 22 years old Krish who visits the following blogs (metblogs.com, kiruba.com, blogspot.com, aparnasblog.wordpress.com) said that it is fun bashing the blog author.

\section{Alternating the Dominant Flow of Conversation}

Conversational domination is regarded as one of the most important elements of social interaction (Burgoon \& Dunbar, 2006; Jayagopi, Hung, Yeo, \& Gatica-Perez, 2009) and this is evident in digital conversations on the blogosphere because as seen in highly interactive blogs, some individuals or groups of "online friends" tend to control or manipulate the discourse. While many other users choose not to be in a position of responsibility, some other blog users try to alternate the dominant flow of conversation. For example, when 33 years old Madu was asked about why she involves herself in digital conversation. She said 
"People's views; if I see comments already, I could put a comment. I could counter someone's view". In Baumer, Sueyoshi, and Tomlinson's (2008) study, they found that that out of fifteen respondents who participated in their study, eleven interviewees accedes that they come across assertions which they dissents but only four interviewees shared situations where the dominant discourse differed from their opnion and they expressed disagreement.

\section{Digital Conversational Perks}

The discourse on use of monetary incentives to motivate people to work, operate, engage or participate has earned considerable scholarly attention in many areas of the society over the years. One distinctive one that is beginning to gain newer interest by the scholarly community is keeping internet users' attention through monetary incentives. This, to some digital natives, is unreliable and unsustainable because it is believed that monetary incentives change the goals for the audience. Those who pose this opinion believe that instead of visiting websites, blogs, Facebook, Twitter Instagram or Snapchat pages to gratify cognitive, affective needs, personal integrative or social integrative needs (Katz, Gurevitch, \& Hass, 1973), audience member/users are motivated to come for the money and not the content which means that once the money stops, the audience might stop visiting. Some others say that online engagement increases when audience/users are told that they are instrumental to the success of the group (Ludford, Cosley, Frankowski, \& Terveen., 2004) through compensation and that is what matters most.

Many of the blog readers interviewed in this study said that they involve themselves in the digital conversations for the commenting perks. For some it is a cross-sectional run while for others, it is a longitudinal run. Those who are in the cross sectional run comment at intervals or only when the giveaway has been announced for luck of been selected while those in the longitudinal run, comment every other time, engage heavily in digital conversation, create funny or awkward names or are steadily controversial so that they blogger can notice them and regard them as the most consistent blog visitors. For Sarunmi, a 21-year-old student/entrepreneur states that; "The main reason why I comment is at times she asks her followers to comment on a post. I comment when it is during her giveaway". This is regarded as cross sectional. Similarly, 30-year-old civil servant Daramola said “... She does this end of the month giveaway. I think she made a post and I saw it so I dropped my email". Interviewees suggested that the likelihood of getting a reward for involving oneself in digital 
conversation is enough reason to do so. 22 years old National Youth Service Corp (NYSC) member old, Aliyu also shared the same sentiment. As for her, she doesn't really involve herself in the digital conversations on the blogs. One of the few posts she commented on provided us the sample of this study. When asked further why she did, she said "I comment because it's her giveaway".

\section{Interests}

Blogs do not only alleviate digital conversations among blog visitors and author, it also gives room for the development and maintenance of common interests and, also an identification with a new social group in the community (Wei, 2004). These set of interests range from one blog to another. For special information blogs, shared interests mostly emerge from the main focus of the blog or what the blog author writes about. For example, for special information blog such as Perez Hilton, top Hollywood gossip blog, the sets of interests that is most likely to emerge from the comment section revolves around celebrity's family and work life. General information blogs such as Linda Ikeji focus on everything and interests that are mostly likely to emerge from such blogs are highly generic.

Many respondents accede that they involve in digital conversations when blog entries or ongoing conversation matches their interest. 48 years old industrial chemist, Aremu said "the kinds of stories I comment on has to do with government or politics. He gave an example of how he heavily engaged in digital conversations during Nigerian's 2015 general election. Similarly, 28 years old civil servant, Bislam, who has been visiting the blog for the past six years said the topic must have to interest; "When it comes to politics, general knowledge, sports, economics or entrepreneurship, I do comment because I am interested in them". Surprisingly, not all interviewees involved themselves in digital conversation because of a specific interest. Offering another perspective, 35 years old Human resource practitioner, Priesthood said "I comment on all news; whatever. For example, news entries about a new artist, new music from an established artistes or even advertisements".

\section{Conclusions}

The blog visitors interviewed provided three primary reasons why they are motivated to be involved in digital conversations on the blogosphere; opinion sharing (Checking other commenters/ blogger and alternating the dominant flow of conversation), conversational 
perks and interest. Based on our results, it is evident that activities of blog visitors are highly understated and, despite the fact that bloggers' role and position in the blogosphere overshadows the blog readers, the contribution and experience of the blog users is an integral part of the blogging activity (Baumer, Sueyoshi, \& Tomlinson, 2008).

"In general, blogs support interpersonal meaning production by producing space and opportunities for communication through the circulation and discussion of topics" (Schmidt, 2006, p. 136). As we've seen based on the themes discussed, respondents are motivated to involve themselves in conversations based on specific reasons they have owned overtime and that is why "not all entries are successful at drawing comments or responses" (Graf, 2012, p. 2768). If the entry doesn't resonate with them they simply ignore and move to the next one.

Although, it is impossible to generalise findings of this study to the Nigerian blogosphere, this study makes important contributions. First, considering that audience-centred blogging research has earned less scholarly attention, this study helped broaden the scope of blog reading research. Secondly, this study provides newer insights as to why some blog visitors engage in digital conversations on the blogosphere. Since this study evaluated why people involve themselves in digital conversations. Future studies might evaluate the relationship between blog author and blog visitors since observations from this study reveals that most blog readers' assertion reveals a connection with the author more than the blog with the use of pronouns such as 'her' and 'she' to address blogging visiting activities. 


\section{References}

Bauer, M., \& Gaskell, G. (2000). Qualitative Researching with Text, Image and Sound: A Practical Handbook for Social Research. London, UK: SAGE Publications.

Baumer, E., Sueyoshi, M., \& Tomlinson, B. (2008). Exploring the Role of the Reader in the Activity of Blogging. Proceedings of the SIGCHI Conference on Human Factors in Computing Systems (pp. 1111-1120). ACM.

Bukvova, H., Kalb, H., \& Schoop, E. (2010). What we Blog? A Qualitaive Analysis of Researchers' Weblogs. In ELPUB , (pp. 89-97).

Braun, V., \& Clarke, V. (2006). Using Thematic Analysis in Psychology. Qualitative Research in Psychology, 3 (2). pp. 77-101.

Burgoon , J. K., \& Dunbar, N. E. (2006). Nonverbal Expressions of Dominance and Power in Human Relationships. In V. Manusov, \& M. Patterson, The Sage Handbook of Nonverbal Communication. Thousand Oaks, CA: Sage.

Efimova, L., \& De Moor, A. (2005). Beyond Personal Webpublishing: An Exploratory Study of Conversational Blogging Practices. Proceedings of the 38th Annual Hawaii International Conference on (pp. 107a-107a). IE.

Elega, A. A., \& Özad, B. A. (2017). New Media Scholarship in Africa: An Evaluation of Africa-focused Blog Related Research from 2006 to 2016. 2017, Quality \& Quantity, $1-16$

Elega, A. A., \& Özad, B. A. (2018). Variety, a Spice of Life: Exploring the Blog Reading Practices of Nigerian General Interest blog, Linda Ikeji's readers. 2017, Manuscript under Review.

Ewins, R. (2005). Who are You? Weblogs and Academic Identity. E-learning and Digital Media: 2(4), 368-377.

Fidel, R. (1993). Qualitative Methods in Information Retrieval Research. Library \& Information Science Research, 15 (3), 219-247. Retrieved from Fidel, R. (1993). Qualitative Methods in Information Retrieval Research.

Graf, H. (2012). Examining Garden Blogs as a Communication System. International Journal of Communication, 6, (22), 2758-2779.

Herring, S. C., Kouper, I., Paolillo, J. C., Scheidt, L. A., Tyworth, M., Welsch, P., . . Ning Yu. (2005). Conversations in the Blogosphere: An Analysis "From the Bottom Up". Proceedings of the 38th Annual Hawaii International Conference on (pp. 107b-107b). IEEE. 
Hookway, N. (2008). 'Entering the Blogosphere': Some Strategies for Using Blogs in Social Research. Qualitative Research, 8(1) 91-113.

Ifekandu, C. C. (2017, 9 15). The Fallout of Nigeria's Anti-Gay Law and Opportunities for the Future for LGBTI Persons And CommunitieS. Retrieved from https://hivos.org/sites/default/files/10._the_fallout_of_nigerias_antigay_law_and_opportunities_for_the_future_for_lgbti_persons_and_communities_by_ chiedu_chike_ifekandu.pdf

Jayagopi, D. B., Hung, H., Yeo, C., \& Gatica-Perez, D. (2009). Modeling Dominance in Group Conversations Using Nonverbal Activity Cues. IEEE Transactions on Audio, Speech, and Language Processing, 17(3), 501-513.

Katz, E., Gurevitch, M., \& Hass, H. (1973). On the Use of Mass Media for Important Things. American Sociological Review, 38 (2), 164-181.

Kaye, B. K., \& Johnson, T. J. (2011). Hot Diggity Blog: A Cluster Analysis Examining Motivations and Other Factors for why People Judge Different Types of Blogs as Credible. Mass Communication and Society, 14(2), 236-263.

Lehti, L. (2013). Between Public and Private: Conversationalisation in French Politicians' Blogs. Journal of Language and Politics, 12(4), 508-536.

Ludford, P. J., Cosley, D., Frankowski, D., \& Terveen., L. (2004). Think Different: Increasing Online Community Participation Using Uniqueness and Group Dissimilarity. Proc. of ACM CHI, (pp. 631-638).

McGlohon, M., Leskovec, J., Faloutsos, C., Hurst, M., \& Glance, N. (2007). Finding Patterns in Blog Shapes and Blog Evolution. Computer Science Department, 533.

Meho, L. (2006). E-Mail Interviewing in Qualitative Research: A Methodological Discussion. Journal Of The American Society for Information Science and Technology, 57 (10), 1284-1295.

Nardi, B. A., Schiano, D. J., \& Gumbrecht, M. (2004). Blogging as Social Activity, or, Would You let 900 Million People Read Your Diary? Proceedings of the 2004 ACM conference on Computer supported Cooperative Work (pp. 222-231). ACM.

Reid, A. (2011). Why Blog? Searching for Writing on the Web. Writing Spaces: Readings on Writing, 302.

Rodi, C. (2002). The Blogs are a Comin'. Blacksburg: Virginia Polytechnic Institute and State University. 
Sankaram, K., \& Schober, M. F. (2015). Reading a Blog When Empowered to Comment: Posting, Lurking, and Non-interactive reading. Discourse Processes, 52(5-6), 406433.

Schmidt , J. (2006). Weblogs. Eine kommunikationssoziologische Studie [Weblogs. A Communication Sociological Study]. Konstanz, Germany: UVK Publishing.

Schmidt, J. (2007). Blogging Practices: An Analytical Framework. Journal of Computer-Mediated Communication, , 12(4), 1409-1427.

Siles, I. (2012). The Rise of Blogging: Articulation as a Dynamic of Technological Stabilization. New Media \& Society, 14(5), 781-797.

Stern, J. (2008). Introduction to Web 2.0 Technologies. Retrieved from http://www.ictliteracy.info/rf.pdf/Web2.0_Introduction.pdf

Turnbull, G. (2002). The State of the Blog Part 2: Blogger Present. In J. Rodzvilla, We've Got Blog: How Weblogs Are Changing Our Culture (pp. 81-85). Cambridge: MA: Perseus Publishing.

Vuorinen, K. (2017, 9 12). Using Weblogs for Discussion (Master's thesis). Retrieved from http://www.museumtwo.com/publications/MSI_257-274_simon.pdf

Walker, D. M. (2006). Blog Commenting: A New Political Information Space. Proceedings of the Association for Information Science and Technology, 43(1), 1-10.

Wei, C. (2004). Formation of Norms in a Blog Community. In L. Gurak, S. Antonijevic, L. Johnson, C. Ratlif, \& J. Reyman, Into the Blogosphere. Rhetoric, Community, and Culture of Weblogs. http://blog.lib.umn.edu/blogosphere/ formation_of_norms.html.

Wheeler, M. (2008). How Noninstitutionalized Media Change the Relationship between the Public and Media. Law and Contemporary Problems, 135-153, 71 (4). 